\title{
Exploring the role of the industrial-organisational psychologist as counsellor
}

\begin{tabular}{|c|c|}
\hline \multicolumn{2}{|l|}{$\begin{array}{l}\text { Authors: } \\
\text { Hanri Barkhuize } \\
\text { Lené I. Jorgense } \\
\text { Lizelle Brink }^{1}\end{array}$} \\
\hline \multicolumn{2}{|c|}{$\begin{array}{l}\text { Affiliations: } \\
{ }^{1} \text { WorkWell, Research Unit for } \\
\text { Economic and Management } \\
\text { Sciences, North-West } \\
\text { University, Potchefstroom } \\
\text { Campus, South Africa }\end{array}$} \\
\hline \multicolumn{2}{|c|}{$\begin{array}{l}\text { Correspondence to: } \\
\text { Lené Jorgensen }\end{array}$} \\
\hline \multicolumn{2}{|c|}{$\begin{array}{l}\text { Email: } \\
\text { 10094598@nwu.ac.za }\end{array}$} \\
\hline \multicolumn{2}{|c|}{$\begin{array}{l}\text { Postal address: } \\
\text { Private Bag X6001 (Internal } \\
\text { Box 114), Potchefstroom } \\
2520 \text {, South Africa }\end{array}$} \\
\hline \multicolumn{2}{|c|}{$\begin{array}{l}\text { Dates: } \\
\text { Received: } 16 \text { Jan. } 2014 \\
\text { Accepted: } 19 \text { May } 2014 \\
\text { Published: } 17 \text { Oct. } 2014\end{array}$} \\
\hline \multicolumn{2}{|c|}{$\begin{array}{l}\text { How to cite this article: } \\
\text { Barkhuizen, H., Jorgensen, } \\
\text { L.I., \& Brink, L. (2014). } \\
\text { Exploring the role of the } \\
\text { industrial-organisational } \\
\text { psychologist as } \\
\text { counsellor. SA Journal of } \\
\text { Industrial Psychology/ } \\
\text { SA Tydskrif vir } \\
\text { Bedryfsielkunde, 40(1), Art. } \\
\text { \#1193, } 11 \text { pages. http:// } \\
\text { dx.doi.org/10.4102/sajip. } \\
\text { v40i1.1193 }\end{array}$} \\
\hline \multicolumn{2}{|c|}{$\begin{array}{l}\text { Copyright: } \\
\text { (C) 2014. The Authors. } \\
\text { Licensee: AOSIS } \\
\text { OpenJournals. This work } \\
\text { is licensed under the } \\
\text { Creative Commons } \\
\text { Attribution License. }\end{array}$} \\
\hline \multicolumn{2}{|l|}{ Read online: } \\
\hline arda & $\begin{array}{l}\text { Scan this QR } \\
\text { code with your } \\
\text { smart phone or } \\
\text { mobile device } \\
\text { to read online. }\end{array}$ \\
\hline
\end{tabular}

Orientation: Industrial-organisational (I-O) psychologists are often confronted with counselling interventions in the workplace and thus it is vital that they are effectively prepared for their role as workplace counsellors.

Research purpose: The aim of this study was to review the role of I-O psychologists as counsellors and to ascertain whether these practitioners are effectively prepared for this purpose.

Motivation for the study: I-O psychologists are mainly concerned with the deep-rooted problems individuals experience in the workplace, and they therefore need appropriate counselling skills. However, it is not clear whether graduates in this discipline receive adequate training for this role.

Research design, approach and method: A qualitative research design with convenience and snowball sampling of 22 participants was utilised. Participants were practising I-O psychologists across Gauteng and North West (South Africa). Semi-structured in-depth interviews were used to gather data, which were transcribed verbatim and analysed using content analysis.

Main findings: Participants were familiar with the meaning of counselling and confirmed that they are faced with a range of counselling situations requiring a unique set of skills and competencies. Based on these findings, participants made recommendations for the future training of I-O psychologists and recommended that counselling be included in the scope of practice of I-O psychologists.

Practical/managerial implications: The role of the I-O psychologist requires training in shortterm therapeutic techniques and counselling in tertiary education.

Contribution/value-add: The study clarifies the role of the I-O psychologist as a counsellor that will ensure that I-O psychologists can be trained more effectively for this role.

\section{Introduction}

Industrial-organisational (I-O) psychology deals with human behaviour and work-related issues (Van Vuuren, 2010). However, I-O practitioners are often influenced by aspects that lie beyond the borders of the workplace, such as cultural influences, family responsibilities and traumatic events (Landy \& Conte, 2004; Van Vuuren, 2010). Strümpfer (2007) mentions that these deeprooted problems of individuals are a big concern for the I-O psychologist. Therefore, the necessity for additional endeavours to elucidate the roles of I-O psychologists in South Africa should be emphasised (Barnard \& Fourie, 2007).

\section{Research purpose and objectives}

According to Nelson (2012), it is the role of the I-O psychologist to assist and support employees in the workplace. In turbulent times, this might include assisting employees who were exposed to traumatic incidents or personal problems (Landy \& Conte, 2004; Van Vuuren, 2010). It seems evident that I-O psychologists need to be effectively prepared for their role as workplace counsellors. The purpose of this study was to explore the role of I-O psychologists as counsellors in order to determine if practitioners consider their skills to be adequate and whether they are effectively prepared for this purpose. Based on the research purpose, the following research objectives were set:

1. To conceptualise the I-O psychologist as a counsellor as defined by the literature.

2. To determine how I-O psychologists define the concept of counsellor.

3. To determine what type of workplace counselling situations practising I-O psychologists are faced with.

4. To make recommendations for the future training of I-O psychologists in counselling skills. 
5. To make recommendations for the scope of practice of I-O psychologists in terms of counselling.

\section{Literature review}

The I-O psychologist as counsellor: In South Africa, psychologists who specialise in the psychology of work and human behaviour in organisations are referred to as I-O psychologists (Nelson, 2012). I-O psychology is the study of human behaviour in the workplace and applying the knowledge of psychology to solve work-related problems (Van Vuuren, 2010). As a result of factors that influence workplace behaviour, which do not always originate within the work setting, the domain of the I-O psychologist extends beyond the physical boundaries of the workplace (Landy \& Conte, 2004; Van Vuuren, 2010). It is clear that problems related to people in the workplace provide I-O psychology with the reason for its existence (Landy \& Conte, 2004; Van Vuuren, 2010). Moalusi (2001) states that it is important to pay attention to the issues pertinent to the South African workplace. At the organisational level, I-O psychology is considered to be one of the most critical fields to human welfare, because people spend most of their lives occupied with work-related activities (Landy \& Conte, 2004; Van Vuuren, 2010).

Strümpfer (2007) states that I-O psychology is the application of general psychology in the workplace. According to Strümpfer, I-O psychology should be viewed as a specialised field within the larger field of psychology that focuses on the workplace (Van Vuuren, 2010). Ryan (2003) is concerned with how the field fits into the broader field of psychology. Perloff (2005) states that during the past 50 years, 'I-O psychology has drifted from its roots in mainstream psychology to its current alliance with practical business aims' (p. 95). Employees experience emotional and psychological problems for which they require counselling (Cristiani \& Cristiani, 1979). If I-O psychologists should choose to move away from their roots in psychology, they run the risk of becoming technicians, focusing on the traditional issues of human resource management (Perloff, 2005).

Strümpfer (2007) explains that I-O psychologists are involved in the entrenched problems influencing people's lives, suggesting that it is the responsibility of the I-O psychologist to embark upon resolving these problems. Therefore, Perloff (2005) considers I-O psychology to be facing a crossroad due to the investment in the dimensions of the individual and the pressure not to neglect these investments. I-O psychologists who really wish to influence the way in which organisations function are not content to be technicians (Perloff, 2005). Barnard and Fourie (2007) investigated the role of the I-O psychologist and found the role of a counsellor to be evident in both current and future roles.

\section{I-O psychology counselling interventions}

Many factors exist that influence workplace behaviour and these do not always originate within the work setting (for example, family responsibilities, cultural influences and non- work-related events such as traumatic events). The domain of the I-O psychologist thus extends beyond the physical boundaries of the workplace (Landy \& Conte, 2004; Van Vuuren, 2010). I-O psychology does not focus on employees only, but also considers the context within which they work (Landy \& Conte, 2004; Moalusi, 2001). I-O psychologists serve to facilitate responses to issues and problems at work by serving as advisors. This is accomplished through their role as scientists who derive principles of individual, group and organisational behaviour through research and apply it to gain solutions to the problems at work (Landy \& Conte, 2004). In essence, the functions of I-O psychologists are varied and consist of conducting research aimed at obtaining comprehensive knowledge and understanding of the behaviour of humans relating to work, productivity and organisations (Cascio, 2001; Rothmann \& Cilliers, 2007; Schreuder \& Coetzee, 2010; Van Vuuren, 2010). Furthermore, applying this knowledge to improve the efficiency of individuals, groups and entire organisations consequently improves the quality of both individuals' and organisations' lives and levels of psychological well-being (Cascio, 2001; Rothmann \& Cilliers, 2007; Schreuder \& Coetzee, 2010; Van Vuuren, 2006).

The contribution that I-O psychology will make relates to the development and implementation of wellness strategies, including aspects such as health promotions, psychology development programmes and stress management. Future contributions will consist of the wellness of personnel and how to keep individuals proactively healthy in organisations (Barnard \& Fourie, 2007). Organisations need to employ more proactive strategies to keep individuals healthy, especially in the event of trauma, as currently companies typically manage trauma as it arises, but without any proactive thinking (Barnard \& Fourie, 2007). One way of accomplishing the aforementioned is through workplace counselling.

According to the Health Professions Council of South Africa (HPCSA) (personal communication, 2011), a qualified I-O psychologist should be able to 'apply knowledge, theories and techniques of psychology to develop and implement interventions to enhance and/or promote individual, group or organisational well-being and optimal functioning'. Furthermore, the I-O psychologist should have the ability to identify, understand and promote various aspects of psychological well-being and resilience. The HPCSA further refers to the I-O psychologist's ability to identify factors working against such well-being and resilience, to enhance the optimal functioning of individuals, groups, families and communities and to facilitate individual and group processes for effective organisational functioning. Perloff (2005) mentions that a high percentage of I-O psychology interventions include counselling and that this should be even higher in future.

\section{Counselling skills and competencies}

In a study conducted by Carducci et al. (1987), I-O psychologists reported that clinical and counselling skills, including effective listening and interviewing skills, were in 
the top five in the list of skills that respondents viewed as most essential for their practice. The I-O psychologist's role is evolving into that of counsellor and will thus require the necessary skills and knowledge. This includes skills such as empathy, communication and listening skills (Pienaar \& Roodt, 2001). Graduates often lack the interpersonal skills and knowledge, as well as the intrapersonal awareness, to sufficiently fulfil a helping role in the workplace (Rothmann \& Van Aardt, 2002).

Barnard and Fourie (2007) state that the current I-O psychology curriculum does not address the educational, training and developmental skills needed by I-O psychologists. The changing nature of the I-O psychologist's role will challenge universities in terms of developing and equipping I-O psychologists (Schreuder, 2001). This change in direction is fundamental to the future direction of I-O psychology and will impact on how I-O psychologists are educated and trained (Perloff, 2005). Appropriate knowledge, skills and competencies are required from I-O psychologists to act as change agents and counsellors (Barnard \& Fourie, 2007).

Strümpfer (2007) believes that I-O psychologists should have a training background in counselling. However, most I-O psychology postgraduate programmes do not include a basic counselling component with a practical element that is designed to develop counselling skills (Carducci et al., 1987). Pienaar and Roodt (2001) also state that the role of the I-O psychologist is such that they require training in therapeutic techniques and counselling in tertiary education. Moreover, all I-O psychologists need a thorough introduction to psychopathology (Strümpfer, 2007).

\section{Scope of practice}

I-O psychologists in South Africa belong to a registered body within the HPCSA in the profession of psychology. The Health Professions Act (Act no. 56 of 1974) regulates the actions that I-O psychologists are permitted to perform within the scope of the profession of psychology (Department of Health, 2011). According to the Act, the following acts fall within the scope of practice of I-O psychologists: planning, developing and applying paradigms, theories, models, constructs and principles of psychology in the workplace in order to understand, modify and enhance individual, group and organisational behaviour effectively. Furthermore, I-O psychologists must facilitate individual and group processes for effective organisational functioning and design and implement training programmes for effective organisational functioning. Lastly, the scope of practice includes designing and developing strategies in consumer behaviour, developing interventions to ameliorate poor performance in work settings and designing and implementing programmes based on understanding ergonomics.

A suggested draft of the scope of practice that is currently in development allows the I-O psychologist to:

perform supportive psychological interventions and shortterm therapeutic counselling interventions for the purposes of diagnosing and ameliorating organisational and work-related adjustment challenges and problems, and enhancing the personal functioning of individuals and groups in organisational or workrelated contexts. (Department of Health, 2012, p. 8)

This inclusion allows for I-O psychologists to provide short-term counselling to clients, which suggests that I-O psychologists are in need of effective counselling skills.

Next, the methodology followed in the study will be discussed.

\section{Research design}

In this section, the research approach, strategy and method will be discussed.

\section{Research approach}

A qualitative approach with a phenomenology method was utilised during this study. Qualitative research involves understanding the research topic from the participant's perspective and therefore is usually relatively open and unstructured, rather than relying solely on theory to provide a framework of the research (Struwig \& Stead, 2001). Qualitative researchers focus on exploring, examining and describing people and their natural environments (Orb, Eisenhauer \& Wynaden, 2000). The relevance of counselling for I-O psychologists needs to be understood from the participant's point of view and, therefore, this approach is considered to be suitable for this study. The phenomenology approach is aimed at understanding and interpreting the meaning that participants attach to everyday life (De Vos, Strydom, Fouche \& Delport, 2005). The phenomenology method is applied by means of engaging in the participant's life setting through a naturalistic manner, having interactions and discussions. For this purpose, the researcher decided to utilise interviews with multiple participants who are involved in the phenomenon as the data-gathering method (De Vos et al., 2005).

\section{Research strategy}

The participants involved in this study were practising I-O psychologists from the provinces of Gauteng and North West. Convenience and snowball sampling was utilised during the study. Maree (2007) states that this sampling method is applied in exploratory research when the research is aimed at obtaining an inexpensive approximation of the truth. Practising I-O psychologists in North West and Gauteng were included in the study due to their accessibility. Snowball sampling resulted when the researcher was referred to other willing participants who could be contacted to take part in the study. The inclusion criteria for the research were participants practising I-O psychology and registered with the HPCSA.

\section{Research method Research setting}

The study was conducted by interviewing the I-O psychologists by means of semi-structured interviews at their 
workplaces, in a private setting. Semi-structured interviews were used to allow for more flexibility. This allows the researcher to be guided by a set of predetermined questions that do not dictate the process. In essence, the flexibility allows the researcher to gain a fuller understanding by being able to probe interesting avenues that emerged (De Vos et al., 2005). The context for the interview was explained and permission was obtained to voice record the conversation.

\section{Entrée and establishing researcher roles}

The researcher gained access to the group of participants from the list of registered industrial psychologists in South Africa. The participants were contacted, and when a potential participant displayed a willingness to participate in the study, the researcher arranged an interview date, time and location. A document explaining the nature, objective and content of the study and details of the researcher was sent in advance to participants. An informed consent document was also included, which stated that participation in the study was voluntary in nature, and that participants were at liberty to withdraw from the study at any stage should they wish to do so. In addition, the document informed participants about the use of a voice recorder during the interview. As the study progressed, the researcher was also referred to other participants willing to participate in the study and in this manner the researcher was able to gain access to another pool of participants.

\section{Participants}

The participants were 22 I-O psychologists, mostly women $(68 \%)$; the majority $(26 \%)$ of the participants fell in the age category of 26-30 years. Participants were mostly white $(82 \%)$ and Afrikaans speaking (77\%). With regard to the highest qualification, participants mostly (41\%) held an MCom in industrial psychology obtained between 2001 and 2006. Participants interviewed during the study primarily (59\%) resided in North West, whilst $41 \%$ of the participants were from Gauteng.

\section{Data collection methods}

Semi-structured interviews were used to collect the data. Utilising semi-structured interviews in this regard was compatible with the research study as it allowed for the discussion of counselling skills beyond the boundaries of the questions (Struwig \& Stead, 2001). With the use of semi-structured interviews the researcher was guided by a set of predetermined questions but had some flexibility if an opportunity arose to probe interesting avenues that emerged from the interview (De Vos et al., 2005). In order to ensure that the correct information was obtained from the interview questions and that participants understood the four questions, a pilot study was conducted with three participants. In order to ensure consistency of data collection, the researcher made use of an interview guide containing the following interview questions:

1. In your own words, what do you regard as counselling?

2. What type of workplace counselling situations are you faced with?
3. What recommendations can be made for the future training of I-O psychologists in terms of the development of their counselling skills?

4. What recommendations can be made for the scope of practise of I-O psychologists in terms of counselling?

\section{Recording of data and data analysis}

The interviews were voice recorded and the data was transcribed into a Microsoft Excel $^{\circledR}$ spreadsheet; then interviews were compared to the voice recordings to ensure that no data had been overlooked. After the data was collected and transcribed verbatim, the resultant document was analysed using content analysis. According to Maree (2007), content analysis refers to the process of examining data from multiple angles whilst aiming to identify key findings that will result in understanding and interpretation of the raw data. The first step in the analysis was to read through the information thoroughly to obtain a general sense of the information, after which the data was cleaned. Cleaning the data involves deleting all unnecessary statements (e.g. 'uhm') (Taylor-Powell \& Renner, 2003). Themes and sub-themes were then extracted by means of coding. Coding refers to separating the data into significant analytical units and classifying them. The data was also given to a co-coder, after which the codes were re-examined and agreed upon. Cluster analysis was then used to group together all the similar statements that formed a category, whereafter themes and sub-themes were extracted (TaylorPowell \& Renner, 2003).

\section{Strategies employed to ensure quality data}

Before embarking on the research for the study, a pilot study was conducted with three participants, which enabled the researcher to explore the research questions and the constructs under investigation on a smaller scale (De Vos et al., 2005). The researcher attended qualitative research training and further training in interviewing skills. During interviews, it is vital that the tape recorder is checked on a regular basis, in order to verify that the tape recorder is still working, and for the researcher to pose only one question at a time (McNamara, 2009). McNamara (2009) also suggests that the researcher should provide the participants with a transition between topics and that the researcher should remain in control of the interview. This is applicable in situations where participants stray from the topic, take too long to answer or when time runs out. In order to ensure the quality of data during analysis, a co-coder was used.

Ethical considerations form an essential basis for research. Qualitative studies are frequently conducted in settings that involve the participation of people in their everyday environments. Therefore, any research that includes people requires an awareness of the ethical issues that may derive from such interactions (Orb et al., 2000). An important ethical consideration that was upheld in this study, according to Lichtman (2009), was that the researcher held a responsibility not to intrude on the time, space and personal lives of participants. Another consideration was 
one of data interpretation, as it is expected that a researcher will analyse data in a manner that avoids misstatements, misinterpretations or fraudulent analysis. To ensure this, a co-coder was used and the principle of justice was considered; justice refers to the avoidance of exploitation and abuse of participants. Other important ethical issues that were taken into account were those of informed consent, anonymity, confidentiality, the avoidance of harm and ensuring that research is conducted with responsibility and competence (De Vos et al., 2005). Specific consent relating to the use of a tape recorder was included in the informed consent document that was signed prior to each interview.

\section{Reporting style}

From the transcribed interviews, themes and sub-themes were extracted. These themes and sub-themes were reported non-verbatim. In order to assist the reader, minor modifications involving the exclusion of words were made to some of the interview extracts without affecting meaning (e.g. words and phrases such as 'uhm' and 'and so on') (De Vos et al., 2005). Afrikaans quotations have been translated in order to accommodate different language groups.

\section{Findings}

The results of the study are arranged into various categories, themes and sub-themes, along with quotations supporting the findings. Each category, together with the applicable themes and sub-themes, is explained below. It should be noted that the quotations provided by Afrikaans-speaking participants were translated into English to achieve a central point of communication, that is, to accommodate all language groups. The frequencies of each theme are provided in brackets. It is important to note that the different frequencies refer to the number of times the particular theme was mentioned and not to the number of participants who mentioned the theme.

\section{Category 1: Meaning of counselling}

The data showed that the meaning of counselling can be clustered into four themes, namely facilitation, helping, intervention and addressing an event. Table 1 provides an indication of the participants' meaning of counselling as extracted from the data analysis.

Due to the fact that many of the sub-themes presented across the four themes, one can conclude that most of the participants had a clear picture of the meaning of counselling. There seem to be contrasting opinions regarding the timeframe of counselling. On the one hand, some participants regard counselling as long term, whilst, on the other hand, others regard it as short-term. Below are the descriptions of the meaning of counselling as provided by the different participants.

Facilitation: Counselling is viewed by the participants as a facilitation process, as a long-term process where different approaches are utilised. One such approach is mirroring. The results further indicate that, by facilitating, the counsellor engages in a psychological action with their client and also acts as a sounding board. During facilitation, aspects are identified that prohibit the client from functioning optimally or a specific event is addressed. This facilitation process provides guidance and aids the client to achieve self-insight, enrichment, personal development or a normalisation state or empowers the client with coping skills.

Helping: The participants viewed counselling as a form of helping, a short-term process during which an event or problem is addressed that has occurred in a client's life. The goal is to assist clients to achieve self-insight. The participants indicated that this can also be done by providing clients with a form of guidance and support, in order to get the client to a point of normalisation. Participants regarded it as important that help should be provided by a trained professional as they possess certain skills.

Intervention: A counselling intervention was seen by participants as addressing an event that has occurred in a client's life. A process then follows by providing the client with guidance throughout the counselling process.

Short-term intervention: Some participants were of the opinion that an intervention is regarded as a short-term process that takes place to address a life event. The goal of a short-term intervention is for the client, with the help of a trained professional, to achieve a point of optimal functioning.

Next, the counselling situations I-O psychologists are faced with in their workplaces are discussed.

\section{Category 2: Counselling situations that I-O psychologists face}

The themes in Table 2 emerged from asking participants what counselling situations they are confronted with. Although the majority of the participants had faced counselling situations, a small number of participants had not.

From the results presented in Table 2, it appears that the I-O psychologists are counselling across numerous fields.

Career counselling: According to the participants, career counselling involves clients who have uncertainty regarding their career and study choice. During career counselling, issues relating to job dissatisfaction and job-person fit are also addressed.

Coaching: Most participants indicated that coaching involves the personal development of clients by equipping them with those skills that can add to their development.

Employee Assistance Programme (EAP) counselling: Participants are faced with various EAP counselling 
situations involving the counselling of people diagnosed with HIV and AIDS. Counselling is provided whenever there are reports of low productivity levels or of employees being absent from work. Employees are also referred to EAPs when their physical well-being is endangered or when they are faced with psychological issues. Other aspects that fall under EAP counselling are trauma counselling, workplace violence and matters relating to substance abuse.

Informal counselling: Participants described informal counselling sessions as situations where clients would approach them without having a formal appointment and start discussions relating to problems that they are experiencing.

Marital and relationship counselling: Participants reported that they are faced with marital and relationship counselling. This refers to situations where conflict emerges and participants have to deal with divorce and mediation. Domestic trauma has also been the subject of counselling.
Psychometric assessment feedback: Participants reported that psychometric assessment feedback can result in a counselling situation. This is because deep-rooted discussions originate from psychometric assessment.

Personal problems: Participants reported that counselling situations also involve clients discussing problems that they are experiencing, such as burnout, work-life balance and financial stress.

Workplace counselling situations: Most participants indicated that these situations occurred within the workplace. Participants also mentioned they were confronted with situations requiring conflict management. Other employees were confronted with substance abuse and burnout, which resulted in counselling.

Trauma counselling situations: These situations include instances where crime has taken place and assistance was provided. Participants were also faced with situations where

\begin{tabular}{|c|c|c|}
\hline Theme & Sub-theme & Response \\
\hline \multirow[t]{13}{*}{ Facilitation (22) } & Achieving self-insight & 'You really only facilitate the process to lead them to the answer that they sometimes already have.' \\
\hline & Enrichment & $\begin{array}{l}\text { 'But an enhancement of a person; they might feel they would like to have a little bit of enhancement or enrichment in their } \\
\text { lives, and that serves as counselling for me.' }\end{array}$ \\
\hline & Guidance & 'Then counselling is there to provide guidance or direction.' \\
\hline & $\begin{array}{l}\text { Identifying what prohibits } \\
\text { optimal function }\end{array}$ & $\begin{array}{l}\text { 'I think counselling is more about trying to give a person insight or to realise what is preventing the person from functioning } \\
\text { fully, whether in the workplace or as an individual.' }\end{array}$ \\
\hline & Long term & 'I think it is to see someone for a longer period, for more than one session.' \\
\hline & Mirroring & 'And with mirroring, to actually reach his own answers.' \\
\hline & Normalisation & 'To place the person back into the situation before the bad incident took place.' \\
\hline & Personal development & 'It's about the facilitation of a process that a person must go through for developmental purposes.' \\
\hline & Psychological action & $\begin{array}{l}\text { 'You walk a personal path with them, and there is a psychological element to it; it is a psychological deed or action where you } \\
\text { then dig deeper.' }\end{array}$ \\
\hline & Sounding board & 'But to then be the sounding board, and then going on a journey and walking the road with him.' \\
\hline & Teaching coping skills & 'You should have that ability just to counsel them, facilitate a process of either coping skills.' \\
\hline & Address an event & 'Counselling, for me, is when someone comes to you with a problem or a question or a challenge.' \\
\hline & Using different approaches & $\begin{array}{l}\text { 'Trying to understand what is going on, and find out how you can help the person, and give some guidance, and with the } \\
\text { different therapies you then use.' }\end{array}$ \\
\hline \multirow[t]{11}{*}{ Helping (28) } & Achieving self-insight & $\begin{array}{l}\text { 'That you will give a guy the chance to organise his own thoughts and help him in the process, and in the process make him } \\
\text { aware of his blind spots, which they usually do not see, and then you help him to generate his own solutions.' }\end{array}$ \\
\hline & Trained professional & $\begin{array}{l}\text { 'Counselling, I would say, is where a trained professional, like a psychologist, in any context, tries to assist a willing participant } \\
\text { with problems they may have in that context, be it work or at home or whatever.' }\end{array}$ \\
\hline & Guidance & 'And I then just guide them in the process.' \\
\hline & Normal life challenges & $\begin{array}{l}\text { 'So, what I understand by counselling is, basically, helping someone in our scope through relatively normal life challenges, } \\
\text { particularly within the workplace.' }\end{array}$ \\
\hline & Normalisation & 'It is to help people deal with things they go through, and to then continue with their lives as normal as possible.' \\
\hline & Personal problems & $\begin{array}{l}\text { 'It's not job-related, it is not a production problem or leadership problem or something like that; it is more an individual } \\
\text { problem.' }\end{array}$ \\
\hline & Short-term & $\begin{array}{l}\text { 'But my idea of counselling is really to provide someone with counselling, in the short-term, who is experiencing a problem, } \\
\text { giving them the necessary shoulder to cry on if it is needed.' }\end{array}$ \\
\hline & Support & 'Counselling is one-on-one, first of all, and helping the individual I see the one-on-one process as supporting somebody.' \\
\hline & To address an event & 'I understand by counselling helping someone through in our scope through relatively normal life challenges.' \\
\hline & Utilising skills & 'That serves as counselling for me, and I obviously use certain skills to help that person.' \\
\hline & Workplace problems & $\begin{array}{l}\text { 'That a person presents with a problem and, specifically from an industrial psychologist's viewpoint, it will most probably relate } \\
\text { to work situations.' }\end{array}$ \\
\hline \multirow[t]{4}{*}{ Intervention (5) } & Trained professional & 'From a trained professional.' \\
\hline & Following a process & 'And the process that follows from there.' \\
\hline & Guidance & 'And then counselling is there to give direction or to give guidance.' \\
\hline & To address an event & 'Something happens in a person's life that is outside of their normal activities or normal life.' \\
\hline \multirow[t]{3}{*}{$\begin{array}{l}\text { Short-term } \\
\text { intervention (4) }\end{array}$} & Achieve optimal functioning & $\begin{array}{l}\text { 'But from of our paradigm, we use short-term therapeutic interventions. We work with relatively normal people, so between } \\
\text { pathology and normal, we work with them to get them to optimal.' }\end{array}$ \\
\hline & Trained professional & 'Not-long term intervention I see it as a short-term process where, as a professional, I would be able to sit down with a person.' \\
\hline & To address an event & 'It is basically about people with relatively normal work-related problems.' \\
\hline
\end{tabular}


family members who lost someone to suicide required counselling.

No counselling situations: Some participants also mentioned that their work is of such a nature that they are not faced with any counselling situations.

\section{Category 3: Recommendations made for the future training of I-O psychology students}

Participants were required to make recommendations regarding the training of future I-O psychology students in terms of counselling.
Participants reported that, in addition to receiving formal training in counselling, students would benefit from receiving additional training in emotional intelligence, conflict management, as well as HIV and AIDS counselling. The results indicated that future students should be trained not only in the different psychometric assessments, but also in how to provide feedback on sensitive psychometric results. Participants reported that in-depth counselling training, with emphasis on the psychology aspect, should be included, along with indigenously focused counselling training (based on South Africa's diverse cultures), training on the various types of counselling models and theories and trauma counselling training.

TABLE 2: Counselling situations that I-O psychologists face.

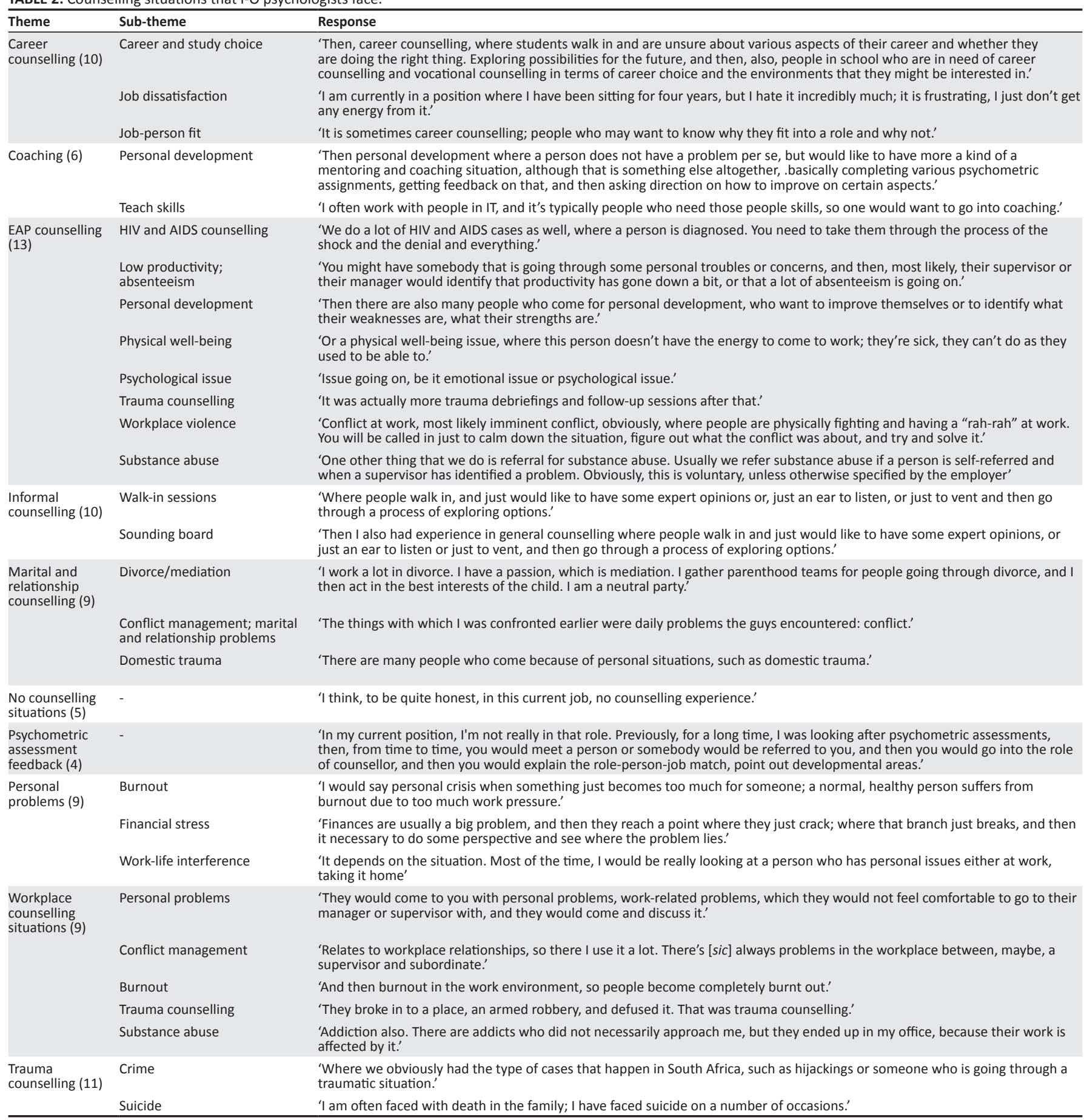




\section{Category 4: Inclusion of counselling in the I-O psychologist's scope of practice}

Lastly, participants were asked to indicate whether they believe counselling should be included in the scope of practice of the I-O psychologist. The main themes are reported in Table 3.

From Table 3, two themes were identified:

Counselling should form part of I-O psychologists' scope of practice: Participants reported that counselling should form part of I-O psychologists' scope of practice, due to the fact that their work environment requires them to work with people on a daily basis, which results in them being confronted with counselling situations. The inclusion will contribute to making them better equipped and prepared to handle these counselling situations. The participants also felt that, when confronted with counselling situations, they are not always in a position to prevent a counselling session from happening and that referral is not always an immediately available option. Some participants reported that including counselling in the scope of practice makes business sense, as businesses can avoid paying two people for a job that one person has the ability to do. In conclusion, participants felt that since the term psychologist forms part of their title, it should be formally recognised that the I-O psychologist is also, in fact, a psychologist.

Counselling should be included in the scope of practice, with revisions: This theme emerged due to the participants reporting that counselling should be included in the I-O psychologist's scope of practice, but with revisions. Firstly, participants mentioned that counselling by the I-O psychologist should be defined and that the duration of the counselling needs to be clarified in terms of counselling being short-term or long term and how many sessions it will consist of. Lastly, participants mentioned that counselling should be included, but that the counsellor should be trained in a specialised field.

\section{Discussion}

The purpose of this study was to explore the role of I-O psychologists as counsellors. The aim was to determine with which type of counselling situations practitioners are faced and to determine whether they are effectively prepared for this purpose. From the results, it was clear that I-O psychologists are aware of the process of counselling and are in fact faced with various counselling situations in their workplaces. Participants made recommendations for the future training of I-O psychologists. Furthermore, most participants also felt that counselling should be included in the scope of practice of I-O psychologists.

The first objective of the study related to the I-O psychologist as counsellor as described in the literature. Literature indicates that industrial psychology is defined as the study of human behaviour in organisations (Cascio, 2001; Van Vuuren, 2010). However, research indicates that, in practice, it is clear that the task of the I-O psychologist is far more complex than this definition suggests. Van Vuuren (2010) states that the boundaries of I-O psychologists are not limited to the physical workplace only, as a wide range of emotional and personal factors (such as family responsibilities and traumatic incidents) could also affect the workplace behaviour of individuals. From the literature it is clear that I-O psychologists should in fact be prepared to deal with workplace counselling situations. This supports findings from Strümpfer (2007) emphasising the fact that the responsibility lies with the I-O psychologists to resolve these aspects, even though they do not stem from the workplace itself.

The second objective of the study related to how I-O psychologists defined the concept of counselling. Most of the participants reported that when counselling is conceptualised, facilitation comes to mind. Participants viewed facilitation as a form of counselling that aims to assist individuals in achieving self-insight, stimulate enrichment and identify what prohibits individuals from functioning optimally and in turn enhance the personal development of individuals. A study conducted by Cilliers (2000) supports this view of facilitation, stating that facilitation is a personcentred approach, in which personal growth and learning are provided.

Participants also viewed counselling as a form of helping as a short-term process, during which an event or problem

TABLE 3: Inclusion of counselling in the I-O psychologists' scope of practice.

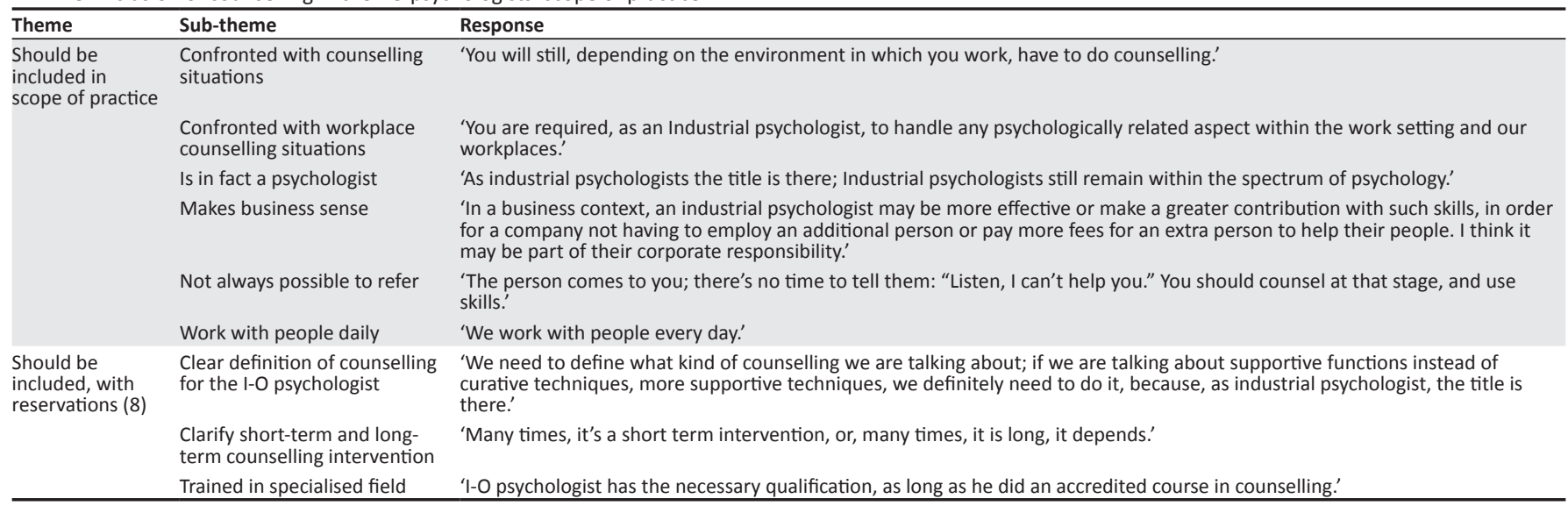


is addressed that has occurred in a client's life. Participants reported that the goal of helping is related to assisting clients to achieve self-insight and to supporting the client in gaining a sense of normalisation. A similar goal is stated by NelsonJones (2006), who wrote that the goals associated with counselling relate to helping clients overcome deficiencies in their normal functioning or addressing changes associated with developmental tasks at various life stages and assisting clients to attain higher levels of functioning.

A third theme that was found in the results related to intervention as a type of counselling situation. Most participants indicated that an intervention is a process of counselling that addresses an event that has occurred in the client's life by providing guidance throughout the counselling process. This is in accordance with Rao (1991), who states that counselling is a significant aspect of guidance and that the term 'guidance' is often used synonymously to counselling. According to the participants, the goal of a short-term intervention is for the client to achieve a point of optimal functioning with the help of a trained professional.

From the results of the second objective of the study it seems clear that most of the participants who are confronted with counselling situations in their workplace view their role as that of facilitator, giving guidance and offering help and running an intervention process. Thus, counselling in this context can be seen as a process of growth and learning, in order for the client to regain control and responsibility over their life or to manage their life better.

The third objective of the study related to determining what type of workplace counselling situations practising I-O psychologists are faced with. The first theme that was reported by participants in this regard related to career counselling where a client experiences uncertainty regarding career and study choice. During these sessions, issues relating to job dissatisfaction and job-person fit are also addressed. This finding corresponds with findings from Schreuder and Coetzee (2010), who report that I-O psychologists are involved in the field of career psychology, career guidance and career development, which all relate to the I-O psychologist's area of expertise. Participants further reported the process of coaching as being a situation that they are faced with that is closely related to counselling. Participants viewed coaching as the personal development of clients by teaching those skills that can add to their personal development. Individuals providing coaching had been trained in this field. Foxhall (2002) reports that effective coaching requires an expert in a diverse array of fields related to learning and development, as well as the leadership development of clients. The fact that I-O psychologists are trained in these fields indicates that they are particularly qualified to provide coaching and that many I-O psychologists already serve as coaches (Society for Industrial and Organizational Psychology, 2013). The American Psychology Association (2013) also reports that coaching employees is a skill utilised by the I-O psychologist.

I-O psychologists reported that they are faced with various EAP counselling situations. This entails counselling being provided following reports of HIV and AIDS diagnosis, low productivity levels or employee absenteeism. Participants reported dealing with EAP-related aspects such as trauma counselling, workplace violence and matters relating to substance abuse. In support of the finding in the study, Van Vuuren (2010) states when an I-O practitioner addresses the wellness of employees, they are affected by external forces such as traumatic incidents and HIV and AIDS. In South Africa, EAP programmes invariably contain an element to address the problem of HIV and AIDS in the workplace (Anderson \& Louw-Potgieter, 2012).

From the results it is clear that participants are sometimes faced with informal sessions, where clients approach them without having a formal appointment and start discussions relating to problems they are experiencing. I-O psychologists further reported that they are confronted with marital and relationship counselling situations. Literature substantiates this finding relating to the strain that has been placed on relationships as a result of work obligations, which is known to be an important factor in marital conflict (Koekemoer \& Mostert, 2010).

Participants reported that feedback relating to sensitive psychometric results often leads to a counselling situation. Providing feedback on the outcome is an important aspect of psychometric assessment (Department of Health, 2011). Considering the potential harmfulness of psychometric tests, the feedback process should be conveyed in a caring and sensitive manner to avoid doing harm (Foxcroft \& Roodt, 2009) and can therefore be viewed as a sensitive counselling situation.

Participants reported that counselling situations also involve clients discussing personal problems that they are experiencing, such as burnout, work-life balance and financial stress. This finding is supported by the studies of Landy and Conte (2004) and Schreuder (2001) which state that I-O psychology has always been involved in the expression of concern for the welfare of workers, thereby relating to job and family matters and stress. Apart from addressing personal problems of clients, participants reported dealing with workplace counselling situations. These include providing conflict management and assisting employees in need of substance abuse and burnout interventions. This finding is supported by the work of Landy and Conte (2004) and Van Vuuren (2010), who report that many factors influence workplace behaviour, such as family responsibilities and cultural influences. Participants furthermore reported being confronted with trauma counselling incidents when employees who experienced traumatic experiences such as crime or injury required counselling. From the research of Young, Koortzen and 
Oosthuizen (2012), it is clear that the I-O psychologist's work relates to dealing with trauma counselling situations.

Some participants did report not being faced with any type of counselling situations in their workplaces.

The fourth objective of the study was to make suggestions for the future training of I-O psychologists in counselling skills in order to better prepare students for the workplace counselling situations. The participants reported that I-O psychology students would benefit from receiving additional training in emotional intelligence courses, conflict management as well as HIV and AIDS counselling in addition to formal counselling training. In agreement, Van Vuuren (2010) states that I-O psychologists are affected by forces such as HIV and AIDS and employee relations. Participants reported that future students should be trained not only in the different psychometric assessment tools, but also in how to provide feedback on the results. Additionally, participants reported that students should receive more in-depth counselling training, with an emphasis placed on the psychology aspect. Participants further felt that more attention should be placed on indigenous-focused counselling, or counselling that is specifically focused on South Africa's diverse cultures, along with providing students with training on the various types of counselling models and theories suitable for the South African context. In addition, it was advised that trauma counselling should be included in the training of future I-O psychologists. Training with regard to focus groups and team interventions was also recommended by participants.

Participants mostly reported that the curriculum should be more balanced in terms of theory and practical application and that a fair amount of time needs to be allocated to both aspects. It is therefore important that students are equipped with both adequate theoretical knowledge and practical skills that act to supplement the knowledge and skills necessary to be competent professionals (Corey, 2009). Participants also recommended that more time be allocated to practical training. Having first-hand familiarity with the pitfalls, limitations and constraints of a technique is different from having developed a sound theoretical knowledge of the topic (Society for Industrial and Organizational Psychology, 1999).

The final objective of the study related to the question of whether counselling should be included in the scope of practice of I-O psychologists. Participants' reported that their work environments require them to work with people and people-related problems on a daily basis. This, in turn, results in the I-O psychologists frequently being confronted with counselling situations. Furthermore, inclusion of counselling in the scope of practice will contribute towards equipping I-O psychologists sufficiently to address complex counselling situations. Participants mentioned that when confronted with a counselling situation, referral is not always an immediate possibility (as can be seen from the informal counselling theme in the abovementioned findings) and therefore the I-O psychologists need to be able to address these situations themselves.

\section{Limitations and recommendations}

No study is without limitations and those for this study are reported next, along with recommendations for future research. The first limitation of the study relates to the fact that interviews were only conducted in two provinces and as result the findings cannot be generalised across the rest of South Africa. A language barrier could have acted as a limitation during the interviews because not all of the interviews were conducted in the participant's first language. It could also be that the level of experience in counselling influenced the answering of the questions.

It is recommended that future research should focus on the development of a training module that could be included in the curriculum of I-O psychology students in South Africa.

\section{Practical implications}

From the results it can be seen that care should be taken to equip the I-O psychologist with effective skills for their role as counsellor. The participants of this study dealt with a range of counselling situations. Consequently it is recommended that future research should focus on the development of a training module that could be included in the curriculum of I-O psychology students in South Africa. It is also important to consider how this training module would change the selection process for the postgraduate training of students, as more counselling-oriented programmes would be incorporated in training programmes. Ultimately, training I-O psychologists in effective counselling competencies and skills would contribute to employees' well-being in the workplace, which is at the core of the I-O psychology profession.

\section{Conclusion}

The results of this study echo Strümpfer's (2007) words that I-O psychologists are involved in the entrenched problems influencing people's lives and it is the responsibility of the I-O psychologist to embark upon resolving these problems. Therefore, it is of importance to provide the I-O psychologist with suitable skills training fitting for this responsibility.

\section{Acknowledgements}

The authors would like to acknowledge the financial assistance of the National Research Foundation (grant number 76306) towards this research. The opinions expressed and conclusions arrived at in this article are those of the authors and should not be attributed to the National Research Foundation.

\section{Competing interests}

The authors declare that they have no financial or personal relationship(s) that may have inappropriately influenced them in writing this article. 


\section{Authors' contributions}

H.B. (North-West University) was lead author, wrote up the article and was responsible for data collection and part of the data analysis. L.I.J. (North-West University) was the postgraduate supervisor of the lead author, secondary writer of the literature review, assisted in the data analysis and gave editorial input. L.B. (North-West University) was associate supervisor of the lead author, trained the student in data analysis and assisted in the data analysis.

\section{References}

American Psychology Association. (2013). Public description of industrial and organizational psychology. Retrieved May 02, 2013, from https://www.apa.org/ ed/graduate/specialize/industrial.aspx

Anderson, T.N., \& Louw-Potgieter, J. (2012). An implementation evaluation of a voluntary counselling and testing programme for the human immunodeficiency virus (HIV) and acquired immunodeficiency syndrome (AIDS). South African Journal of Industrial Psychology, 38(1), 1-10.

Barnard, G., \& Fourie, L. (2007). Exploring the roles and contributions of industrial psychologists in South Africa against a multi-dimensional conceptual framework (part 2). South African Journal of Industrial Psychology, 33, 45-53.

Carducci, B.J., Deeds, W.C., Jones, W.J., Moretti, D.M., Reed, G.J., Saal, F.E. et al. (1987) Preparing undergraduate psychology students for careers in business. Teaching of Psychology, 14(1), 16-20. http://dx.doi.org/10.1207/s15328023top1401_3

Cascio, W.F. (2001). Knowledge creation for practical solutions appropriate to a changing world of work. South African Journal of Industrial Psychology, 27, 14-16.

Cilliers, F. (2000). Facilitation skills for trainers. South African Journal of Industrial Psychology, 26, 21-26.

Corey, G. (2009). Theory and practice of counseling and psychotherapy. (8th edn.) Belmont, CA: Thomson Brooks/Cole.

Cristiani, T.S., \& Cristiani, M.F. (1979). The application of counselling skills in the business and industrial setting. The Personnel and Guidance Journal, 58, 166-169. http://dx.doi.org/10.1002/j.2164-4918.1979.tb00374.x

De Vos, A.S., Strydom, H., Fouche, C.B., \& Delport, C.S.L. (2005). Research at Grass roots: For the social sciences and human service professions. (3rd edn.). Pretoria, South Africa: Van Schaik Publishers. http://dx.doi.org/10.1016/j. atmosres.2004.10.015

Department of Health. (2011). Health Professions Act, 1974: Regulations defining the scope of the profession of psychology. Government Gazette, 34581, notice 10505. Pretoria, South Africa: Government Printer.

Department of Health. (2012). Health Professions Act, 1974: Draft discussion document. Regulations defining the scope of the profession of psychology. Government Gazette, 16 July 2012. Pretoria, South Africa: Government Printer.

Foxcroft, C., \& Roodt, G. (2009). Introduction to psychological assessment in the South African context. Cape Town, South Africa: Oxford University Press.

Foxhall, K. (2002). More psychologists are attracted to the executive coaching field. American Psychological Association, 33(4), 52.

Koekemoer, E., \& Mostert, K. (2010). An exploratory study of the interaction between work and personal life: Experiences of South African employees. SA Journal of Industrial Psychology/SA Tydskrif vir Bedryfsielkunde, 36(1), 801-816.

Landy, F.J., \& Conte, J.M. (2004). Work in the 21st century: An introduction to industrial and organizational psychology. New York, NY: McGraw-Hill.

Lichtman, M. (2009). Ethical issues in qualitative research. Retrieved May 03, 2013, from http://www.uk.sagepub.com/upm-data/27011_4.pdf

Maree, K. (2007). First steps in research. (1st edn.). Pretoria, South Africa: Van Schaik Publishers. http://dx.doi.org/10.1016/j.dsr.2006.12.001
McNamara, C. (2009). General guidelines for conducting research interviews. Retrieved May 02, 2013, from http://managementhelp.org/businessresearch/ interviews.htm

Moalusi, K.P. (2001). Repositioning industrial psychology for the creation of new futures in turbulent times. South African Journal of Industrial Psychology, 27, $17-21$.

Nelson, T.M. (2012). Industrial and organisational psychology in South Africa: Research and practice. Unpublished master's dissertation, University of Witwatersrand, Johannesburg, South Africa.

Nelson-Jones, R. (2006). Essential counselling and therapy skills: The skilled client model: London, England: Sage Publications.

Orb, A., Eisenhauer, L., \& Wynaden, D. (2000). Ethics in qualitative research Journal of Nursing Scholarship, 33(1), 93-96. http://dx.doi.org/10.1111/j.15475069.2001.00093.x

Perloff, R. (2005). What lies ahead for $1 / 0$ psychology and psychologist-managers. The Psychologist-Manager Journal, 8(1), 89-96. http://dx.doi.org/10.1207/ s15503461tpmj0801_8

Pienaar, Y., \& Roodt, G. (2001). Die teenswoordige en toekomstige rolle van bedryfsielkundiges in Suid-Afrika [The current and future roles of industria psychologists in South Africa]. Suid-Afrikaanse Tydskrif vir Bedryfsielkunde, 27, 25-33.

Rao, S.N. (1991) Counselling and guidance. (2nd edn.). New Delhi, India: Tata McGraw-Hill

Rothmann, S., \& Cilliers, F.V.N. (2007). Present challenges and some critical issues for research in industrial/organisational psychology in South Africa. South African Journal of Industrial Psychology, 33(1), 8-17.

Rothmann, S., \& Van Aardt, E.C. (2002). Die evaluering van ' $n$ ontwikkelingsprogram in fasilitering vir studente in die gedragswetenskappe [The evaluation of development programme in facilitation for students in the behavioural sciences]. Suid-Afrikaanse Tydskrif vir Bedryfsielkunde, 28(1), 37-43.

Ryan, A.M. (2003). Defining ourselves: I-O psychology's identity quest. The IndustrialOrganizational Psychologist, 41(1), 21-33.

Schreuder, D. (2001). The development of industrial psychology at South African universities: A historical overview and future perspective. Journal of Industrial Psychology, 27(4), 2-7.

Schreuder, D., \& Coetzee, M. (2010). An overview of industrial and organisational psychology research in South Africa: A preliminary study. South African Journa of Industrial Psychology, 36(1), Art. \#903, 11 pages. http://dx.doi.org/10.4102/ sajip.v36i1.903

Society for Industrial and Organizational Psychology. (1999). Guidelines for education and training at the doctoral level in Industrial-Organizational psychology. Retrieved September 22, 2013, from http://www.siop.org/PhDGuidelines98.aspx

Society for Industrial Organizational Psychology. (2013). Industrial and organizational psychology. Retrieved September 22, 2013, from http://www.siop.org/history/ crsppp.aspx

Strümpfer, D.J.W. (2007). Lest we forget that industrial and organizational psychology is psychology. South African Journal of Industrial Psychology, 33(1), 1-7.

Struwig, F.W., \& Stead, G.B. (2001). Planning, designing and reporting research. Cape Town, South Africa: Pearson Education South Africa.

Taylor-Powell, E., \& Renner, M. (2003). Analyzing qualitative data. Retrieved October 01, 2013, from http://learningstore.uwex.edu/assets/pdfs/g3658-12.pdf

Van Vuuren, L.J. (2006). Industrial psychology: Goodness of fit? Fit for goodness? Inaugural address. Unpublished master's thesis, University of Johannesburg, Johannesburg, South Africa.

Van Vuuren, L.J. (2010). Industrial psychology: Goodness of fit? Fit for goodness? South African Journal of Industrial Psychology, 36(2), 1-16. http://dx.doi. org/10.4102/sajip.v36i2.939

Young, M., Koortzen, P., \& Oosthuizen, R.M. (2012). Exploring the meaning of trauma in the South African Police Service: A systems psychodynamic perspective. South African Journal of Industrial Psychology, 38(2), 183-194. http://dx.doi. org/10.4102/sajip.v38i2.1004 